\title{
Book Review: Tiffany Lethabo King's The Black Shoals
}

\author{
Reviewed by Adrianne Bacelar de Castro
}

Adrianne de Castro is a Brazilian educator with years of experience working in elementary and secondary schools in Brazil. Her MA thesis was inspired by common worlds pedagogies and thinking with, rather than mastering concepts of, materials and others of shared worlds. Her approach to early childhood education is collectivist and inclusive of more-than-humans. Her research is a humble response toward more livable worlds in the present human-modified geological epoch of the Anthropocene. Email: $\underline{\text { abacelar@uwo.ca }}$

Sitting with Black women from all over the earth has made me think a great deal about what it means to be indigenous, and what my relationship as a Black woman in North America is to the land-rights struggles of the indigenous peoples of this land, to Native American Indian women, and how we can translate that consciousness into a new level of working together. In other words, how can we use each other's differences in our common battles for a livable future? (Lorde, 1985, p. 109)

Lorde's journal entry evokes the kind of ethics from which this book holds space. The shoal invokes a material, constructed, and imagined ecotonal space of becoming where ceremony is also geography. In her journal entry, Lorde wonders whether a conversation with Native women is possible and asks "how we can translate that consciousness into a new level of working together. In other words, how can we use each other's differences in our common battles for a livable future?" (King, 2019, p. 72)

The year 2020 was devasting. How do we want life to move on from it? Wildfires, climate-induced catastrophes, the novel coronavirus, and the murder of a Black American caught on camera. Those were life-changing events with consequences throughout the world. Robert Kunzig (2020) claims that, since 2020, being vulnerable might be a universal feeling: "Climate extremes, the pandemic, and police violence all lead us to become aware of the same feeling: vulnerability" (p. 78). Throughout different spaces and communities, the catastrophic events have connected people, but the effects are felt unequally. For example, across the United States, the statistics show that the virus is much deadlier to Black people (Sutton, 2020). Such vulnerability pushes me to consider not only how we want to move on from these conditions, but also how we got to this place.

In this moment of history, it has never been more relevant to ask oneself Audre Lorde's and Tiffany King's questions about creating livable futures together. In a move to question my commitments and role in these turbulent times, I joined other graduate students in reading books and publications from Black feminist writers. We searched for readings that might trouble our practice as academic researchers in education and as pedagogists working in early learning spaces in these challenging times.

Education, including early learning, is a political project, and as such is always entangled with questions of living well together. Peter Moss (2014) reminds us that "stories about early childhood education are necessarily framed and shaped by other and more epic stories, meta-narratives about the political, economy, the social condition, the environment-in short, stories about the state we are in" (p. 15). It matters how we take up those questions as educators and how they might implicate the pedagogical work in early learning spaces. Cristina Delgado Vintimilla and Veronica Pacini-Ketchabaw (2020) explain how pedagogical work asks early childhood education to "become ever more attuned to the situated complexities in which we live" (p. 8) and to ponder the (un)answerability of the question "What does it mean to live well with others?" (p. 11). This is a question that is not to be answered but is meant to provoke us to continually think about our pedagogical work and its larger implications.

In this essay, I review The Black Shoals by Tiffany King (2019). I believe it to be an essential addition to a pedagogist's or an educator's "bundle," as scholar and pedagogist Vintimilla calls it. Vintimilla talks about one's bundle that is carefully gathered during one's life. The bundle is the coming together of experiences and ideas nurtured with 
art, science, knowledge, inspirations, and ordinary moments: It is the ideas and concepts that help to orient the pedagogist's practice and thoughts about education. What Tiffany King's book brings is not something to be applied or ideas to be extracted and moved to practice in early childhood. This book is an inspiration for an inclusive practice of possibilities, to think with other creative methodologies. I think about it as a source of ideas to nurture, and that might help us see, rethink, and possibly transform aspects of our practices in early childhood educationaspects that are silently and not so silently contributing to the environment-wrecking, racist, and genocidal project of the creation of Man (Wynter, 2003).

I begin with an analytical summary of Tiffany King's book and how she used the shoal metaphor theoretically and methodologically. I conclude with a set of questions and thoughts on how this book might inspire work in early childhood education.

\section{The shoals}

The Black Shoals disrupts and interrupts Western thought through its chapters as it delves into literature, Black and Indigenous activism, art, and lived experience. It brings a new perspective to theorizing "New World violence, social relations, Indigeneity, and Blackness in the Western hemisphere" (King, 2019, p. 2). It is situated in the space of relationality between Indigenous and Black studies with the shoals concept. In the book's introduction, King explains how the ocean and water metaphor has been focused on by the Black diaspora, emphasizing rootlessness, and how Indigenous studies has been focusing on land to challenge coloniality. Using the shoal concept, she creates a new space to think about Blackness and indigeneity that exceeds the symbolism of ocean/land.

The shoal, defined by geology, is an area where water's body becomes shallow: a shallow place between the sea and the shore. King also thinks of the shoal as a process: "the movement of the ocean from greater to shallower depths" (p. 2). The shoal is a liminal place with many meanings, not possible to map, a place for indeterminacy.

The methodological approach sparked by these ideas of shoal and shoaling works to create analytical openings, crafting alternative grammars and vocabularies. The methodological shoal opens new investigative places that allow for noticing ways where Indigenous and Black trajectories of existence have been essentially connected to each other. The theoretical and methodological shoals disrupt, displace, and blur the binary of land/ocean. In creating this liminal space, King offers a new reading of the past and a coconstituted possible future that reconsiders "relational and ethical spaces of Black and Indigenous scholarship and the liberatory practices of abolition and decolonization" (p. 31).

King makes an intentional move to read Black and Indigenous lives outside Westerncentric modes of speech and understanding. She does this by discussing some of the ways settler colonial studies, for example, addresses colonization as a structure rather than focusing on the inherent colonial violence of genocide and slavery. At its core, the book discusses Indigenous genocide and slavery through conversations between Indigenous and Black studies, leaving white Western academic and political discourse out. Simultaneously, it brings new grounds to understand the human - and perhaps the possibility of being human differently-beyond the rubric of conquest.

In the first chapter, King writes about the use of language to describe colonization and its relations to Indigenous genocide and slavery, calling it "errant grammars" (pp. 36-73). The chapter begins by describing an event where a statue of Christopher Columbus in Boston was defaced with red paint and tagged with the sentence "Black lives matter." King uses the event as a point of convergence between Indigenous and Black studies. The image of Columbus as discoverer and explorer is so powerful that it erases his role in the violent, genocidal, and slave-based conquest of the Americas. King writes: "This aspect of conquest, a violent and repetitive process of making the 
modern human through extinguishing Black and Indigenous life, is disavowed and willfully forgotten" (p. 39). She brings the contested figure of Columbus, a figure attached to violence by both Native and Black studies, to think about conquest. Relying on a robust tradition of interrogating the formation of the human in Black and Native studies, and more specifically how Man was invented through and made possible by making Indigenous and Black life a space of death, she proposes to focus on the grammars of conquest instead of the grammars of settlement (settler colonial studies).

King proposes the grammars of conquest and flesh: "Attending to the lingua franca of conquest and flesh will enable a different perspective from which to attend to the ways black and native studies continue to be in conversation about and struggle against the project of the human" (p. 55). Emphasizing genocide and slavery instead of settler colonialism reveals that settlement was always connected to the violence of genocide in the making of the New World. King highlights how the word settler is not adequate and not harsh enough to frame the colonial relations. In this chapter, she creates a space where Native and Black studies can share a language.

In the second chapter, King takes two different readings of William Gerard De Brahm's 1755 South Carolina and Georgia map (https://mesda.org/item/collections/a-map-of-south-carolina-and-part-of-georgia/1508/). In the first, she reads the map as an attempted conquest and settlement: "De Brahm, the settlers in South Carolina, and the British Crown enacted their own, unique form of conquistador humanism by cartographically writing themselves onto the landscape of the Atlantic Low Country though renderings of Black fungibility and Indigenous disappearance" (p. 84). The map has a list of names and titles of white proprietors of the lands and, at the same time, it brings slave workers into the illustration in the bottom right of the map and shows the displacement of Indigenous peoples (who are absent from the map except for an arrow that points to a route away from the Cherokees). In this first reading of the map, she points at the listed names as the representation of what was considered human and the possessors of things; the slaves were pictured there as fungible, products that were bought and sold and who represented the fecundity of this promising British colony. In her second reading, King reads the map as anxious, saying, "Another spatial story that needs to be attended to is that the map was also a reflection and record of white settlers' fears." The map was created in the wake of the Stono Rebellion and after a series of Cherokee insurrections against the white settlers. This map is portrayed in the second reading as an attempt to control Black and Indigenous rebellions that were always happening.

In Chapter 3, King puts De Brahm's map into conversation with Julie Dash's film Daughters of the Dust (1991). The overlapping readings of De Brahm's map and Dash's film create tensions and frictions between the map (as an attempted conquest) and Dash's decolonial work that shows other ways of being human that are not under the rubric of conquest. According to King, Dash does a counter reading of the indigo plantation, disrupting visions of death and labour in her film. King reads the map and the film as porous; they become sites of possibility for creating an alternative cartography that allows for reimagining the plantation scenes. In this chapter, she transforms the shoal metaphor into a metaphor of the pore. She thinks about Dash's poetic move when she portrays the hands of Nana Peazant, the main character, as permanently stained blue by the indigo. She thinks with the pores of the hands of enslaved Black people who worked on indigo plantations. The pore represents the entrance and the edge of the body simultaneously, an opening and an end. King thinks about the pore as a site of death, almost inhabitable:

The nether region of the indigo plantation is a liminal space that represents a space that is at once both inside and at the very edge of the plantation. It is also a place teetering on the edges of life and death. (p. 113)

The indigo plantation is seen as the edge and at the same time as the beginning of a space where enslaved people could love and have an alternative social conviviality away from the enslavers' eyes. In this chapter, she calls her 
shoal methodology bricolage. This methodology works, and she puts different texts, literature, film, and objects together to create her analytical framework. She relies on the work of Leanne Simpson to disrupt the human/morethan-human binary as she reads the plantation from Nana Peazant's stained blue hands: "Our bodies are embedded in the ecologies and in our intimate relationships with the land" (p. 114). King shows the scale of violence through those stained hands by this overlapping of the map, the film, and Black and Native feminist writers such as Sylvia Wynter, Katherine McKittrick, Saidiya Hartman, and Leanne Simpson.

Chapter 4 connects two erotic tales. One tale by Julie Dash talks about the relationship between Iona Peazant and St. Julien Lastchild (characters from the film Daughters of the Dust and the novel that gave a sequel to the story). The other tale is The Cherokee Rose: A Novel of Ghosts and Gardens (2015) by Tiya Miles. The erotic stories narrate attachment between Indigenous and Black characters. In this chapter, King thinks about these relationships as representing "acts of decolonial worldmaking (p. 144). She addresses how the erotic has been used by poets like Audre Lorde and Billy-Ray Belcourt to affirm Black and Indigenous lives in alternatives ways to those dominated by suffering and death. It allows us to think about Black and Indigenous futurity, the erotic as a liberatory space. King explains: "In the context of this chapter and this project, 'liberatory' means a space of possible futurity for Black and Indigenous people" (p. 144).

In Chapter 5, King uses as a point of departure Charmaine Lurch's sculpture Revisiting Sycorax and brings excerpts of an interview with the artist where she talks about how her work is inspired by the work of Sylvia Wynter (adaptation of the notion of demonic) and interconnected with the mathematical formula of the Tesseract. Lurch explains how the Tesseract can transform 3D into 4D. It is about creating a new space. King also thinks with "exilic thought" she encounters in the works of Charmaine Lurch, Dionne Brand, Katherine McKittrick, and Rinaldo Walcott that "unsettles hegemonic, and often congealed, national and regional hegemonies within diaspora studies" (p. 175). This chapter is a space of transformation in her shoaling movements, with ceremony as the break with the old traditions and the initiation of the new (p. 205).

In the end, King thinks about the concept of ceremony and explains how each chapter of the book was about different ceremonies. She began with the \#BlackLivesMatter ceremony of defacing the statue of Columbus in Chapter 1 and ended in Chapter 5 with Charmaine Lurch's sculpture, "the wiggling and distortion of the line ... creat [ing] new aesthetics that invoke human ceremony on new terms that invite us to shape what it means to be alive" (p. 206). Together the different ceremonies that compose the book create "shifting and new grounds" (p. 206) to rethink humanity.

\section{Discussion and concluding thoughts}

As I mentioned in the introduction, I propose reading this book, not as something to possibly reproduce, but as a source of inspiration to think about the grammars of practice for early childhood education. Engaging with humans' violent makings from the 15th century until today can help us think about questions of how our work in early childhood education can be part of a story of conquest or a practice that engages in thinking about how to be human differently.

Inspired by King's writings, I think that the possibilities of how to be human differently do not mean limiting ourselves to a response of moral outrage as we realize that this violence is perpetrated continually through the $21^{\text {st }}$ century and as people face police brutality or the unequal effects of COVID-19 on Indigenous, Black, and economically marginalized communities. Moral outrage is not enough because that kind of response might put a period into the conversations. What King does with her shoaling movement in this book is, instead, about using commas, brief pauses, and interrogations that keep the thinking and the conversation moving. 
There are interesting questions to ponder with King's work. When she brings the idea of conquest as more generative than settlement for Native and Black lives and histories during colonization, we interrogate language and discourse. Early childhood education is permeated with discourses about childhood, such as psychologybased developmentalism, that have been framing the early learning spaces for decades. How do we navigate the different discourses of childhood in education? How might some discourses be contributing to a liberal humanist project of making the human? Blaise and Ryan (2012) show how critical theory has been essential to question normative views of young children and to question the developmentally based curriculum as inclusive and unbiased. As Blaise and Ryan acknowledge the role of critical theory in education, they simultaneously claim the need to create transformation and "reinvent what it means to teach young children" (p. 89). When we think about creating a practice that moves beyond the idea of a scientific child (Dahlberg, Moss, \& Pence, 2013), an idea that has been shaping the field for decades, we might get some inspiration from King's shoaling moves in Chapter 3 when she reads De Brahm's map and Dash's film as speculative texts. King reads De Brahm's map as a map of the desires and fabulations of the British conquistadors. She does not read it as a scientific text that tells an irrefutable truth, thus she opens thinking about the map's limitations and working toward new possibilities-a multitude of stories. At the same time, the limits of this Cartesian object bring new imaginings for Black and Indigenous lives-lives not defined exclusively by stories of suffering. King's reading of the map shows the limits of liberal humanism theorizations while concurrently opening possibilities for thinking about being human in different ways not inscribed in Westerncentric thought. How might it inspire different kinds of thought about Westerncentric childhood discourses and how they influence quotidian practices? How could it provoke new openings and possibilities created by engaging with art, poetry, and literature?

As we carefully add these ideas to our bundle and nurture them, we might rethink ways that we include materials (books, illustration, toys) to satisfy diversity requirements in early childhood spaces, as is expected in the profession. How could we include books, ideas, and concepts into our spaces because they might be transformative and generative of practices that challenge anti-Blackness and anti-indigeneity? We need to go beyond what is demanded and try to think with other objects and behaviours that might be contributing to maintaining and restricting Black and Indigenous lives to stories of conquest and suffering. One object we usually have in educational settings is the map itself. How can we imagine other ways to take an item such as the familiar map of Canada found in classrooms and childcare centres across Canada and reimagine how we engage with it? How can we think more deeply and critically of what it means to put this map up on the wall? When posting a map of Canada as a practice, could we not include questions and provocations? Can we reimagine the map? Create new possibilities? Canada is the country with the most extensive coastline in the world. We have more shoals than anywhere else. Can this area of indeterminacy (Canadian shoals) help us rethink this map? As an early childhood educator myself, I wonder about the simple act of posting a map on the wall, provoked by the shoaling and imaginings Tiffany King proposes.

As I claim, education is political. It matters what questions we choose to pose and what stories we choose to think with. I conclude by returning to the opening quotes as I suggest that we think seriously about our choices when we work with children, because they are always contributing to larger political projects, even when we are unaware. We might think about how can we include antiracism intentionally in our practices, engaging creatively and finding interdisciplinary inspirations in our field. This is a collective work that leads us to continually ask Lorde's question, and King's: "How can we use each other's differences in our common battles for a livable future?" 


\section{References}

Blaise, M., \& Ryan, S. (2012). Using critical theory to trouble the early childhood curriculum: Is it enough? In N. File, J. J. Mueller, \& D. B. Wineski (Eds.), Curriculum in early childhood education E-examines, rediscovers renewed (pp. 80-91). Routledge.

Dahlberg, G., Moss, P., \& Pence, A. (2013). Beyond quality in early childhood education and care: Languages of evaluation (3rd ed.). Routledge.

Dash, J. (Writer, Director). (1991). Daughters of the dust \{Film]. Kino International.

King, T. L. (2019). The black shoals: Offshore formations of black and native studies. Duke University Press.

Kunzig, R. (2020). Let's not waste this moment: We need to stop abusing the planet. National Geographic, 238(5), 76-89. https://www. nationalgeographic.com/magazine/article/lets-not-waste-this-crucial-moment-we-need-to-stop-abusing-the-planet-feature

Lorde, A. (1985). I am your sister: Black women organizing across sexualities. Kitchen Table, Women of Color Press.

Miles, T. (2015). The Cherokee rose: A novel of ghosts and gardens. Blair.

Moss, P. (2014). Transformative change and real utopias in early childhood education. Routledge.

Sutton, W. (2020). What COVID-19 took from this Black community. National Geographic, 238(5), 36-39.

Vintimilla, C. D., \& Pacini-Ketchabaw, V. (2020). Weaving pedagogy in early childhood education: On openings and their foreclosure. European Early Childhood Education Research Journal, 28(5), 628-641. https://doi.org/10.1080/1350293X.2020.1817235

Wynter, S. (2003). Unsettling the coloniality of being/power/truth/freedom: Towards the human, after man, its overrepresentation-An argument. The New Centennial Review, 3(3), 257-337. https://doi.org/10.1353/ncr.2004.0015 